\title{
Aspects of healthcare efficiency in the framework of ensuring the longevity of the population and socio-demographic security of the region
}

\author{
Natalya Krivenko ${ }^{1 *}$, and Daria Epaneshnikova ${ }^{1}$ \\ ${ }^{1}$ Institute of Economics, Ural Branch of the Russian Academy of Sciences, 620014, Ekaterinburg, 29 \\ Moskovskaya St Russia
}

\begin{abstract}
The article considers modern demographic trends, in the conditions of medical care cost increasing and aging of the population. The expediency of studying aspects of health care efficiency is justified. The relationship and mutual influence of changes in the country's economy and changes in the health care system are revealed. The problems of preserving the health of the population are considered comprehensively, taking into account the influence of environmental factors, behavioral factors and attitudes to human health, the effectiveness of public policy implementation and the effectiveness of the health system. An integrative model for evaluating the effectiveness of regional health care is proposed based on an integrated approach aimed at improving the population health and ensuring social and demographic security of the region. The integrative model is adapted on the example of the Sverdlovsk region. In dynamics for 2008-2018, improved medical and demographic indicators and high effects were achieved as a result of comprehensive measures to neutralize factors that have a negative impact on the health of the population, promotion and implementation of healthy lifestyle, strengthening state support for the industry, and the successful functioning of regional health care.
\end{abstract}

\section{Introduction}

The main demographic trend in recent decades has been the "aging of the population" - a pronounced trend of increasing the share of older citizens in the age structure of almost all countries of the world. According to UN forecasts [1], this process will continue and by 2050 the share of the elderly population will reach $16 \%$, partly due to a decrease in the share of the able-bodied population. The most developed countries and Russia have both a higher proportion of the elderly population and a higher rate its of increase. In high-income countries, the share of elderly people increased between 1950 and 2015 from $8 \%$ to $17 \%$, in Russia from $5 \%$ to $13 \%$, and by 2050 it will reach $27 \%$ in developed countries and $22 \%$ in our country. In general, from 1950 to 2050, the share of the elderly population in the world will increase by 3.1 times, in developed countries - by 3.4 times and in Russia - by 4.6

*Corresponding author: nvkrivenko@yandex.ru 
times [2]. A number of recent studies have not found a relationship between labor productivity and age [3]. In other words, contrary to the stereotype, an increase in age does not necessarily entail a decrease in labor productivity. This is also indicated by studies of the cognitive abilities of the elderly people [4]. In a number of foreign works $[5,6]$, attention is focused on the need for measures to improve the quality of human capital (implementation of the concept of continuing education, measures that contribute to the extension of a healthy life, etc.). If the quality of human capital remains at a high level in older age, this has a positive impact on labor productivity, as well as reduces expenditures on other social programs [2]. In the context of the continuing trend of population aging, research on the effectiveness of the health system, which has a direct impact on the preservation of human potential and ensuring the longevity of the population at the regional level, is of scientific interest.

\section{Materials and methods}

The research is based on the example of health care of the Sverdlovsk region, one of the largest regions of the Ural Federal district. It is based on the concepts of system economy, sustainable development, and changes, using systematic, multi-level and integrative approaches, methods of statistical, structural, and factor analysis.

Taking into account the heterogeneity, instability, multi-factoricity, multilevelness, polystructure, and fractality of the modern economy, Kleiner G. B. introduced the term of "system economy" [7]. The concept of "sustainable development" was first proposed by the Director General of the World Health Organization Gro Harlem Brundtland. At the UN Conference in Rio de Janeiro in 1987, the world community adopted the concept of sustainable development, the key points of which include the sustainable development of society at all levels (macro, meso and micro levels) based on the interconnection of economic, social, environmental and other processes to meet the needs of present and future generations [8].

Within the framework of the concepts of a systemic economy and sustainable development, it is advisable to consider the Russian economy in close relationship with the branches of the social sphere, including the most important branch - health care in terms of ensuring national demographic security, preserving the labor potential of the population, which ensures the growth of the country's gross domestic product. Within the framework of the theory of changes, the relationship and mutual influence of changes in the country's economy and changes in social sectors, which lead to frequent changes in the conditions of functioning in health care, is traced.

During the period of transformation in Russia, economic growth was determined by the initial transition crisis (1998 to 1989 - minus 44\% of GDP). The conditions for human development in the country during the post-reform period were very difficult, especially in the first decade. The collapse of economic ties in the post-Soviet space created serious problems for the country's residents and millions of migrants from the former Soviet republics [9]. The transformation processes of the Russian economy from 1990 to 2005 in the conditions of mass closure of enterprises were accompanied by drop in the standard of living of most of the population, deterioration of the health system, increase in morbidity and mortality: the indicator of natural population growth per 1000 people, which was 3.9 in 1990 , in subsequent years was replaced by the indicator of population loss per 1000 people: -6.1 in $1995 ;-6.6$ in $2000 ;-5.9$ in 2005.

Taking into account the ambiguous processes in the country's economy that affect the level of financing of the industry, the need to preserve human potential with the rational use 
of limited resources, scientific justification is required for the possibility of improving the effectiveness of the health system at all levels of management.

\section{Results and discussion}

Throughout the history of mankind, society has evaluated the effectiveness of medical activities. In Ancient Egypt, there was a positive feedback: the doctor was economically interested in the duration of the disease, since the fee was charged not for the number and time of visits, but for the duration of the disease. In Ancient China, on the contrary, there was a negative feedback: the doctor was economically interested in the patient's health, receiving a salary as long as the served patients were healthy [10, pp.275 - 276].

At the state level, performed calculations of evaluating the effectiveness of health care are of the interest, presented by academician Rein G. E., the first head of the Ministry of Health of Russia in 1916: reducing the total mortality in Russia from $30.2 \%$ to the Western European level of $18 \%$ allows to save 600.0 million rubles, i.e. 5 times more than all the state's health care costs in that period [10, p. 11].

The concept of human development is aimed at developing the human potential of all citizens as the ultimate goal of economic development. Increasing life expectancy is the most important criterion for the development of the country's human potential [11, pp. 3334].

The problem of population health and life expectancy is one of the key issues for modern Russia. We are 10 years behind for women and 14 years behind for men in terms of life expectancy in developed countries [12, pp.74-75]. In many countries of the WHO European region, the increase in well-being associated with an increase in life expectancy over the period 1970-2003 was $29-38 \%$ of GDP, an amount much higher than the health expenditure of each of these countries [13].

Health affects the time of accumulation of human capital through the length of life and the number of "healthy days". Health losses lead to economic losses related to both treatment and rehabilitation costs and under-produced gross product. In the early 2000s, the annual deterioration in the health of the population employed in the economy was commensurate with the loss of $6.5 \%$ of GDP [14, p.142].

To date, the improvement of medical and demographic indicators, including the life expectancy of the population, largely depends on the effectiveness of health care at all levels of government. It is advisable to study the problems of population health preservation using systematic, multi-level and integrative approaches, methods of statistical, structural, and factor analysis: it is necessary to consider the impact on health of external factors, the attitude to the health of the individual, the implementation of state policy to preserve population health, and the activities of the health system. Changing the health of an individual leads to qualitative changes in his condition. Changing the health of the population at the public level leads to organizational and structural changes in the industry.

Adverse external factors are poor ecology, work in production under harmful conditions, violation of safety at work, which leads, respectively, to the risk of developing chronic, occupational diseases, industrial injuries, and in the future - to significant socioeconomic losses at the society level. In Russia, the main document declaring the need to create a safe environment for people is the Federal Law on sanitary and epidemiological welfare of the population No. 52-Ф3 as amended on 01.07.2017, which includes an article on the need to identify changes and forecast of the health condition of the population and the environment, to establish and eliminate harmful effects on people of environmental factors. For this purpose, the Rospotrebnadzor has created a system of social and hygienic monitoring based on the collection and analysis of statistical information materials from 
various departments. However, this system does not provide an assessment of quantitative relationships between the impact of a particular environmental factor and changes in human health [9]. There are no targeted programs for assessing the impact of adverse environmental factors on population health, using modern methods of evidence-based medicine. Such works are not numerous, their results are not generalized at the federal and regional levels, and there is very little information about their use for management purposes. In this context, it is particularly difficult to determine the environmentaldependent share of population health, which is always an extremely difficult scientific task [9].

The economic rationale for national economy losses due to adverse external factors can be demonstrated on the example of calculated by the scientists of the Institute of Economics, Ural branch of RAS, economic losses from premature mortality of the working population from injury in the Sverdlovsk region in 2000, it amounted to 14 billion rubles, which actualizes the need of increased government measures to prevent them.

It is advisable to analyze the dynamics of the external factors impact on population health and measures to neutralize them on the example of the Sverdlovsk region in 20082018 (table 1).

Table 1. Neutralizing factors that have a negative impact on public health

\begin{tabular}{|l|l|}
\hline \multicolumn{1}{|c|}{ Factors } & \multicolumn{1}{|c|}{$\begin{array}{c}\text { Dynamics of harmful factors neutralization indicators } \\
\text { for 2008-2018. }\end{array}$} \\
\hline Environmental & $\begin{array}{l}\text { Reduction of water intake from natural water bodies for use by 41\%. } \\
\text { Reduction of polluted wastewater discharge to surface water bodies by } \\
36 \% \text {. } \\
\text { Reduction of air pollution emissions from stationary sources by } 34 \% .\end{array}$ \\
\hline $\begin{array}{l}\text { Harmful working } \\
\text { conditions }\end{array}$ & $\begin{array}{l}\text { Precautionary measures of the Sverdlovsk regional Social Insurance Fund } \\
\text { of the Russian Federation. } \\
\text { Growth of expenses for labor protection measures by 1.9 times. } \\
\text { Reduction of the number of persons with diagnosed occupational disease } \\
\text { by 78\%. }\end{array}$ \\
\hline $\begin{array}{l}\text { Occupational } \\
\text { traumatism }\end{array}$ & $\begin{array}{l}\text { Reduction in the number of victims of industrial accidents by } 62 \%, \\
\text { A } 60 \% \text { reduction in the number of man-days of incapacity for work-related } \\
\text { injuries. }\end{array}$ \\
\hline
\end{tabular}

Source: Healthcare in the Sverdlovsk region, 2018: statistical collection, city of Yekaterinburg, 2019.

The positive dynamics of the impact of economic activities on the environment and natural resources for the period 2008-2018 should be noted: reduction of water intake from natural water bodies for use by $41 \%$; reduction of polluted waste water discharge into surface water bodies by $36 \%$; reduction of pollutants emissions into the atmosphere from stationary sources by $34 \%$. The experience of the Sverdlovsk regional Soical Insurance Fund of the Russian Federation shows the effectiveness of preventive measures aimed at the accurate assessment of working conditions, identification of risks threatening the life and health of the employee at each workplace, monitoring the health of workers, prevention of chronic diseases, prevention of disability of able-bodied part of the population: the reduction in persons with diagnosed occupational disease by $78 \%$ and injured in accidents at production site $-62 \%$ [15, pp. 18-25].

Since 2005, Russia has implemented state measures to support health care: the program for additional drug provision for privileged categories of citizens; the National priority project "Health" in 2006-2013; programs for the modernization of healthcare at the level of regions-subjects of the Russian Federation (2011-2013); Federal targeted and state programs for the development of healthcare. 
Since 2018, the State Program of the Russian Federation "Healthcare development" has been transferred to project management. The program includes nine areas (subprograms), the first of which is "Improving the provision of medical care, including the prevention of diseases and the formation of a healthy lifestyle". It is necessary to provide a comprehensive multi-level intersectoral approach to solve the problem of formation of a healthy lifestyle of the population of the Russian Federation [11, p.35].

Over the years of industry reform, the following positive trends have been observed in Russia as a whole [16]:

- Formation of a unified public health system that includes epidemiological monitoring, risk factor analysis, statutory regulation, motivating citizens to a healthy lifestyle, and active involvement of employers and civil society in improving the population health.

- As part of the healthy lifestyle promotion, alcohol consumption per capita has been reduced by almost $40 \%$; tobacco consumption has been reduced: in adults-by $22 \%$, and in teenagers - by 2.5 times; the number of people who regularly engage in physical education and sports increased to $34 \%$.

- $\quad$ Strengthening the preventive focus: since 2013, mass preventive health screenings have been resumed at the modern level. In 2017, 48.5 million people, children and adults, underwent preventive examinations and medical examinations, which is 1.5 times more than in 2013.

- In the Sverdlovsk region in dynamics for 2008-2018 the number of people passed medical examinations increased: adults - by $26 \%$, adolescents - by $70 \%$.

Table 2 presents the main demographic and health indicators in the Sverdlovsk region for 2008-2018, showing the dynamics of the reduced mortality, including as a result of: implementation of the state policy on population health protection, reduction of the harmful impact of economic activities on the environment and natural resources, improvement of labor protection at the enterprises, decrease in level of occupational diseases, injuries, implementation of the healthy lifestyles program, and, of course, the effective operation of the regional healthcare system.

Table 2. Main medical and demographic indicators for the Sverdlovsk region for 2008-2018

\begin{tabular}{|l|l|l|l|l|}
\hline Indicators & 2008 & 2017 & 2018 & $\begin{array}{l}\text { Dynamics of indicators } \\
2018 / 2008\end{array}$ \\
\hline $\begin{array}{l}\text { Natural increase (+), loss (-) of } \\
\text { the population by } \\
1,000 \text { population }\end{array}$ & -2.4 & -1.0 & -1.9 & Decrease in loss by 21\% \\
\hline Maternal mortality, total per. & 15 & 6 & 5 & $\begin{array}{l}\text { Maternal mortality decrease } \\
\text { by } 67 \%\end{array}$ \\
\hline $\begin{array}{l}\text { Infant mortality rate } \\
\text { (per 1,000 live births) }\end{array}$ & 7.6 & 4.9 & 4.7 & $\begin{array}{l}\text { Decrease of infant mortality } \\
\text { by 39\% }\end{array}$ \\
\hline $\begin{array}{l}\text { Number of working-age } \\
\text { deaths, people }\end{array}$ & 18,994 & 13,777 & 13,487 & $\begin{array}{l}\text { Decrease of working-age } \\
\text { mortality by 29\% }\end{array}$ \\
\hline $\begin{array}{l}\text { Population mortality } \\
\text { per 100,000 of population, } \\
\text { including: }\end{array}$ & $1,498.7$ & $1,333.1$ & $1,354.3$ & $\begin{array}{l}\text { Decrease of population } \\
\text { mortality by } 10 \%\end{array}$ \\
\hline $\begin{array}{l}\text { from diseases of the } \\
\text { respiratory system }\end{array}$ & 2,414 & 1,833 & 1,851 & $\begin{array}{l}\text { Decrease of population } \\
\text { mortality by 32\% }\end{array}$ \\
\hline from tuberculosis (all forms) & 21.4 & 10.2 & 9.5 & $\begin{array}{l}\text { Decrease of population } \\
\text { mortality by 56\% }\end{array}$ \\
\hline from neoplasms & 220.9 & 224.7 & 234.4 & $\begin{array}{l}\text { Increase of population } \\
\text { mortality by 6\% }\end{array}$ \\
\hline
\end{tabular}




\begin{tabular}{|l|l|l|l|l|}
\hline $\begin{array}{l}\text { from diseases of blood } \\
\text { circulatory system }\end{array}$ & 834.7 & 654.2 & 653.5 & $\begin{array}{l}\text { Decrease of population } \\
\text { mortality by } \\
22 \%\end{array}$ \\
\hline from external causes of death & 204.5 & 128.9 & 125.1 & $\begin{array}{l}\text { Decrease of population } \\
\text { mortality by } \\
39 \%\end{array}$ \\
\hline
\end{tabular}

Source: Healthcare in the Sverdlovsk region, 2018: statistical collection, city of Yekaterinburg, 2019.

The conducted research allowed us to form an integrative model for evaluating the effectiveness of regional healthcare (table 3). The proposed model considers a comprehensive approach aimed at improving the population health and ensuring social and demographic security of the region.

To neutralize the factors that have a negative impact on the population health, it is advisable to use interdepartmental, program-targeted approaches at the macro, meso and micro levels. Complex of medical preventive technologies of population health risks management in connection with chemical pollution of the environment, implemented in the Sverdlovsk region [17] includes the following: assessment and forecasting of health effects factors of chemical contamination of the environment and establishment of populations at risk; organization and conduct of biological prevention, clinical diagnostics and treatment of diseases, implementation of rehabilitation measures; assessment of medical preventive measures effectiveness, risk communication and development of recommendations to manage the risk to public health.

Table 3. Integrative model for regional healthcare effectiveness assessment

\begin{tabular}{|c|c|c|c|}
\hline $\begin{array}{l}\text { Factors } \\
\text { affecting the } \\
\text { health of the } \\
\text { population }\end{array}$ & $\begin{array}{l}\text { Measures aimed } \\
\text { at improving } \\
\text { public health }\end{array}$ & Efficiency assessment & Resulting effects \\
\hline $\begin{array}{l}\text { Factors that } \\
\text { have a } \\
\text { negative } \\
\text { impact on } \\
\text { public } \\
\text { health }\end{array}$ & $\begin{array}{l}\text { Using an } \\
\text { interdepartmental, } \\
\text { program-oriented } \\
\text { approach at the } \\
\text { macro, meso and } \\
\text { micro levels to } \\
\text { neutralize } \\
\text { negative factors. } \\
\text { An example of the } \\
\text { contribution of } \\
\text { regional } \\
\text { healthcare: } \\
\text { creation in the } \\
\text { Sverdlovsk region } \\
\text { of a system of } \\
\text { medical and } \\
\text { preventive } \\
\text { measures to } \\
\text { manage the risk to } \\
\text { population health } \\
\text { exposed to the } \\
\text { influence of a } \\
\text { chemically } \\
\text { polluted } \\
\text { environment [17]. }\end{array}$ & $\begin{array}{l}\text { Assessment of the } \\
\text { effectiveness } \\
\text { rehabilitation measures and } \\
\text { development } \\
\text { recommendations for risk } \\
\text { management }\end{array}$ & $\begin{array}{l}75-80 \% \text { of children who } \\
\text { underwent biological } \\
\text { prevention of the risk of } \\
\text { developing environmentally } \\
\text { related health disorders and } \\
90-95 \% \text { of children who } \\
\text { underwent rehabilitation } \\
\text { treatment improved their } \\
\text { health indicators. Assessment } \\
\text { of the economic effects of } \\
\text { rehabilitation measures: } \\
\text { prevented economic damage } \\
\text { to public health for the period } \\
2005-2015 \text { amounted to more } \\
\text { than } \\
2 \text { billion rubles, economic } \\
\text { efficiency in } 2015 \text { reached } \\
\text { more than } 8.7 \text { rubles for each } \\
\text { ruble of costs [17]. }\end{array}$ \\
\hline
\end{tabular}




\begin{tabular}{|c|c|c|c|}
\hline $\begin{array}{l}\text { Attitude to } \\
\text { the health of } \\
\text { the person } \\
\text { himself }\end{array}$ & $\begin{array}{l}\text { Promotion and } \\
\text { implementation of } \\
\text { healthy lifestyle }\end{array}$ & $\begin{array}{l}\text { Assessment of } r \text { systemic } \\
\text { prevention and healthy } \\
\text { lifestyle level }\end{array}$ & $\begin{array}{l}\text { High medical, social and } \\
\text { economic efficiency } \\
\text { preventive medicine: } \\
{[1: 8)} \\
{[18, \text { p.117]. }}\end{array}$ \\
\hline $\begin{array}{l}\text { Implementat } \\
\text { ion of the } \\
\text { state policy } \\
\text { to preserve } \\
\text { public } \\
\text { health }\end{array}$ & $\begin{array}{l}\text { The national } \\
\text { priority project } \\
\text { "Health" and } \\
\text { other programs: } \\
\text { increasing } \\
\text { industry } \\
\text { financing, } \\
\text { improving the } \\
\text { provision of } \\
\text { modern } \\
\text { equipment to } \\
\text { medical } \\
\text { organizations, } \\
\text { increasing the } \\
\text { scale of high-tech } \\
\text { medical care, etc. }\end{array}$ & $\begin{array}{l}\text { Multi-factor assessment of } \\
\text { financial cost effectiveness } \\
\text { in healthcare [19]. } \\
\text { The integral indicator of } \\
\text { expenses efficiency: } \\
\text { the ratio of the integral } \\
\text { indicator of service } \\
\text { performance to the indicator } \\
\text { of changes in costs } \\
\text { (financing): } \\
\text { Eint.cost=Iint. perf/I Icost.chg }\end{array}$ & $\begin{array}{l}\text { On the example of the anti- } \\
\text { tuberculosis service of the } \\
\text { Sverdlovsk region: for the } \\
\text { period from } 2012 \text { to } 2017 \text {, } \\
\text { achievement of high integral } \\
\text { performance indicator of } 2.8 \\
\text { due to improvements in the } \\
\text { dynamics of indicators of } \\
\text { morbidity, prevalence, } \\
\text { disability, and mortality. The } \\
\text { integrated cost effectiveness } \\
\text { indicator indicates the } \\
\text { efficient use of financial } \\
\text { resources: } \\
\text { Ec=2.8/1.29=2.2 } \\
\text { The total economic effect of } \\
\text { the decrease in the dynamics } \\
\text { for the period from } 2012 \text { to } \\
2017 \text { of losses in morbidity, } \\
\text { disability, and mortality due } \\
\text { to tuberculosis amounted to } \\
\mathbf{9 0 5 . 6} \text { million rubles. }\end{array}$ \\
\hline $\begin{array}{l}\text { Healthcare } \\
\text { system } \\
\text { performance }\end{array}$ & $\begin{array}{l}\text { Improving } \\
\text { regional health } \\
\text { planning and } \\
\text { management, } \\
\text { implementation of } \\
\text { priority regional } \\
\text { projects, } \\
\text { interdepartmental } \\
\text { target programs, } \\
\text { innovative } \\
\text { organizational, } \\
\text { medical, and } \\
\text { information } \\
\text { technologies: } \\
\text { improving } \\
\text { medical and } \\
\text { demographic } \\
\text { indicators }\end{array}$ & $\begin{array}{l}\text { The multidimensional } \\
\text { economic impact in } \\
\text { healthcare [20]. } \\
\text { The index of } \\
\text { "multidimensional } \\
\text { economic impact in } \\
\text { healthcare": } \\
\text { (Emultidim. }=E_{1}+E_{2}+E_{3}+ \\
\left.E_{4}\right) \\
\text { where } \\
\left(E_{1}\right) \text { - economic effect of } \\
\text { treatment duration reducing } \\
\text { in a } 24 \text {-hour hospital; } \\
\left(E_{2}\right)-\text { economic } \\
\text { effect from reducing the } \\
\text { loss of morbidity; } \\
\left(E_{3}\right)-\text { economic } \\
\text { effect from reducing losses } \\
\text { due to temporary disability; } \\
\left(E_{4}\right)-\text { economic effect } \\
\text { from reducing the loss of } \\
\text { mortality of the working- } \\
\text { age population. }\end{array}$ & $\begin{array}{l}\text { On the example of the cancer } \\
\text { service of the Sverdlovsk } \\
\text { region: achieving a } \\
\text { multidimensional economic } \\
\text { effect for the period from } \\
2013 \text { to } 2017 \text { in the amount of } \\
\mathbf{1 1 6 . 6} \text { million rubles. }\end{array}$ \\
\hline
\end{tabular}




\begin{tabular}{|c|c|c|c|}
\hline & & $\begin{array}{l}\text { Integrative assessment of } \\
\text { regional healthcare } \\
\text { effectiveness } \\
\text { Assessment of medical and } \\
\text { demographic indicators } \\
\text { dynamics. } \\
\text { Calculation of the indicator } \\
\text { of the absolute economic } \\
\text { effect in the healthcare } \\
\text { system as a result of } \\
\text { reducing losses from } \\
\text { morbidity, disability, and } \\
\text { mortality at the level of } \\
\text { society. }\end{array}$ & $\begin{array}{l}\text { Achievement of the absolute } \\
\text { economic effect indicator in } \\
\text { the healthcare system of the } \\
\text { Sverdlovsk region for 2013- } \\
\text { 2017: } \\
\mathbf{9 , 6 7 0 . 2 0} \text { million rubles. }\end{array}$ \\
\hline
\end{tabular}

Collections of statistical materials "Health status of the population and performance indicators of the healthcare system of the Sverdlovsk region" for 2012-2017". URL: https://miacso.ru/index.php/937-sbornik-statisticheskikh-materialov, Federal Treasury Website URL: http://roskazna.ru/ (access date: 28.04.2020).

The effectiveness of implementing the system of medical and preventive measures to manage the risk to public health is characterized by a high amount of prevented economic damage to public health for the period of 2005-2015 - more than 2 billion rubles.

The proposed efficiency assessments demonstrate the achievement of significant economic effects by the example of high performance of health services in the treatment of socially significant diseases (tuberculosis and cancer).

An integrative assessment of the effectiveness of regional healthcare indicates that an absolute economic effect was achieved in the healthcare system of the Sverdlovsk region in 2013-2017 in the amount of 9,670.20 million rubles due to improved management, implementation of interdepartmental, program-oriented approaches, and innovative development of the industry.

\section{Conclusions}

The research has revealed the relationship and interdependence of sustainable development of the country's economy and the most important branch of the social sphere healthcare. The author's proposed integrative model for assessing the effectiveness of regional healthcare allows to comprehensively take into account the main factors that affect the health of the population, identify measures aimed at improving it both from the health system, and from various departments and the population itself, as well as to evaluate the results of changes. The resulting high effect in the healthcare system of the Sverdlovsk region confirms the feasibility of a systematic, multi-level and integrative approach, the need for further progressive transformations of the industry.

\section{Acknowledgment}

The research was carried out with the financial support of the RFBR in the framework of the scientific project No. 19-010-00396 "Efficiency of the health system as a factor of sustainable social and economic development of regions". 


\section{References}

1. World Population Prospects: The 2017 Revision. United Nations, 2017. Available at: https://www.un.org/development/desa/publications/world-population-prospects-the2017-revision.html

2. E.T. Gurvich, M.A. Ivanova, Financial journal 5, 9-22 (2018)

3. P. J. Nicholson, G. Mayho, S. A. Robson, C. Sharp, Ageing and the Workplace. British Medical Association (2016)

4. V. Skirbekk, E. Loichinger, D. Proceedings of the National Academy of Sciences, 109 (3), 770-774 Available at: https://doi.org/10.1073/ pnas.1112173109

5. J. O. Martins., F. Gonand, P. Antolin, de la Maisonneuve C., K.-Y. Yoo OECD Economics Department Working Paper, 420, (2005) Available at: http://dx. doi.org/10.2139/ssrn.700064.

6. C. Nerlich, J. Schroth, ECB Economic Bulletin, 2 (2018)

7. G.B. Kleiner, Economic Issues, 6, 4-28 (2013) doi:10.32609/0042-8736-2013-6-4-28

8. B. Carlef, F. H. Livingsson, Management from A to Z. Concepts and models; trans. from English, 441 (SPb.: Stockholm School of Economics in Saint Petersburg, 2006)

9. Report on human development in the Russian Federation, 292 (2017)

10. V.Yu. Semyonov, Healthcare economics, 11, 275-276 (2004)

11.E.V. Egorov, Social and economic efficiency of public health management: philosophical and methodological foundations. Second annual scientific and practical conference. Moscow, Moscow State University n.a. M.V. Lomonosov, Faculty of Economics, April 23-24, 2018: monograph / edited by L.A. Tutov, E.M. Razumovskaya, Z.R. Ziganshina, 33-36 (Moscow: TEIS, 2018)

12. A.G. Magomedova, Social and economic efficiency of public health management: philosophical and methodological foundations. Second annual scientific and practical conference. Moscow, Moscow State University n.a. M.V. Lomonosov, Faculty of Economics, April 23-24, 2018: monograph / edited by L.A. Tutov, E.M. Razumovskaya, Z.R. Ziganshina, 74-76 (Moscow: TEIS, 2018)

13. Suhrcke, Marc, et al. "Economic damage from poor health: the situation in the European region." Background paper by WHO and the European Observatory on health systems and policies, 28 (2008)

14. B.B. Prokhorov, V.S. Tikunov, Problems of forecasting, 4, 142-144 (2005)

15. E.A. Alshits, I.A. Kulkova, Manager 2 (9), 18-25 (2018)

16. Speech of the Minister Veronika Skvortsova at the Final Board of the Ministry of Health of Russia on March 30, 2018, Electronic resource, http://www.aif.ru/society/healthcare/glava_minzdrava_veronika_skvorcova_my_vidim_ nesovershenstva_sistemy

17. S.V. Kuzmin, V. B. Gurvich, S.V. Yarushin et al., Health of the nation - the basis of Russia's prosperity: proceedings of the X All-Russian Forum (city of Moscow, April 2830, 2016), Moscow: National Health League, 215-221 (2016)

18. V.I. Starodubov, D.V. Piven et al. Health management at the present stage: problems, their causes and possible solutions, 117 (Publishing house "Health Manager",2007)

19. N.V. Krivenko, A.I. Tsvetkov, Regional Economy, 14(3), 970- 986 (2018)

20. N.V. Krivenko, V.G. Elishev, L.A. Kriventsova, Regional Economy, 15 (1), 164-177 (2019) DOI: 10.17059/2019-1-13. 